\title{
Assessing the effect of recreational scallop harvest on the distribution and behaviour of foraging marine turtles
}

\author{
Natalie Wildermann, Christopher Sasso \\ Christian Gredzens and Mariana M. P. B. Fuentes
}

\begin{abstract}
The impact of fisheries on marine megafauna is widely known but most studies have focused on commercial fisheries, overlooking the effect of local recreational fisheries. This is particularly important for marine turtles in nearshore habitats that overlap with recreational fisheries. We assessed the effect of recreational scallop fisheries on the distribution and behaviour of foraging marine turtles in the coastal waters of the upper Eastern Gulf of Mexico. Before and during the scallop season we quantified the density and overlap of marine turtles and vessels sighted, and satellite tracked four turtles to assess their distribution and behaviour. The relative distribution of marine turtles sighted during the scallop season overlapped with $48 \%$ of the area most frequently used by harvesters, and marine turtle activity hotspots shifted between seasons. In addition, during the scallop season the home range size of individual turtles appeared to decrease, and turtles displayed frequent changes in travel speed and directionality. We hypothesize that such changes are probably related to the distribution and movement of vessels and the abundant presence of people in the water. Our study highlights the importance of considering recreational fisheries and their local effect on marine megafauna for informing future adaptive management practices. However, further studies are needed to quantify the direct and indirect impacts of recreational fisheries and to assess the degree of risk of associated activities to marine turtle populations.
\end{abstract}

Keywords Caretta caretta, Chelonia mydas, Eastern Gulf of Mexico, Lepidochelys kempii, marine turtles, recreational fisheries, scallop harvest, wildlife management

The supplementary material for this article is available at https://doi.org/10.1017/So030605318000182

Natalie Wildermann, Christian Gredzens and Mariana M. P. B. Fuentes (Corresponding author) Department of Earth, Ocean and Atmospheric Science, Florida State University, Tallahassee, FL 32306-4320, USA

E-mail mfuentes@fsu.edu

Christopher SAsso National Marine Fisheries Service, Southeast Fisheries Science Center, Miami, Florida, USA

Received 23 October 2017. Revision requested 24 November 2017.

Accepted 18 January 2018. First published online 3 July 2018.

\section{Introduction}

Commercial, recreational and artisanal fisheries can have both direct and indirect impacts on threatened species (Crowder \& Norse, 2008). Of particular concern is bycatch, the unintended capture of non-target organisms during fisheries operations, which is considered to be one of the most serious threats globally to long-lived marine megafauna such as marine turtles (Wallace et al., 2013). Further impacts from fisheries can occur from vessel traffic, which may affect the fitness of individuals, energy expenditure, changes in foraging activity, displacement and disturbance, and mortality (Hazel et al., 2007; Powell \& Wells, 2011; Barrios-Garrido \& Montiel-Villalobos, 2016). As a consequence, there has been substantial effort to evaluate and address the impacts of fisheries on marine megafauna (e.g. Zydelis et al., 2009; Lewison et al., 2014).

Assessments of the interactions between sea turtles and fisheries have focused mainly on commercial fisheries, with little attention to the effects of recreational fisheries (Powell \& Wells, 2011; Altieri et al., 2012; Young et al., 2014). This is an issue as $12 \%$ of the world's population fish recreationally (Cooke \& Cowx, 2004). In the USA recreational fishing averaged over 73 million trips and c. 9 million users annually during 2007-2017 (NMFS, 2017). This may have substantial consequences, both direct and indirect, upon marine environments and species. The few studies conducted to date have shown that recreational fishing and related activities can have profound effects on animal populations and coastal ecosystems, including depletion of fish populations and ecosystem collapse from trophic-level cascades (Cooke \& Cowx, 2004; Altieri et al., 2012; Young et al., 2014).

Recreational fisheries in marine environments are concentrated in coastal areas, which are also home to multiple species and populations of marine turtles. This is the case within the Big Bend Region of north-western Florida, which serves as important developmental habitat for green Chelonia mydas, Kemp's ridley Lepidochelys kempii, and loggerhead Caretta caretta turtles (e.g. Schmid et al., 2003; Barichivich, 2006), and also supports Florida's largest recreational bay scallop Argopecten irradians harvest. The scallop fishery occurs annually from late June to late September (Geiger et al., 2015), a period with water temperatures favourable for marine turtles (Schmid \& Witzell, 2006). 


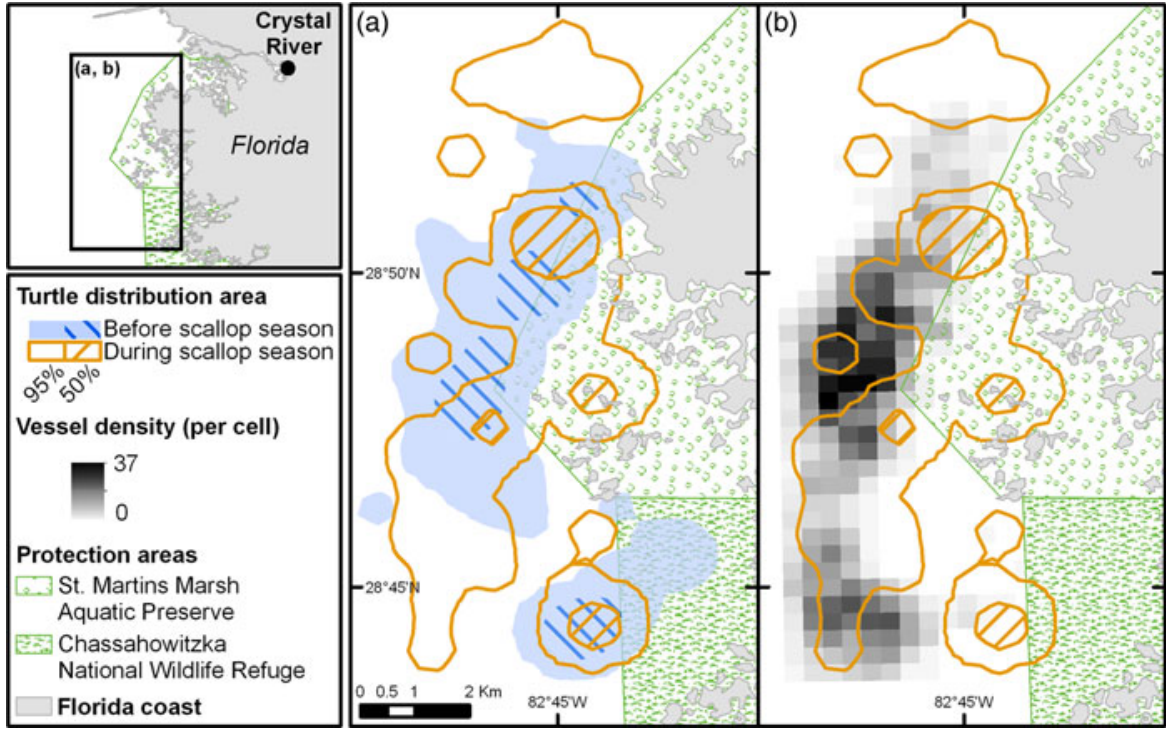

FIG. 1 Spatial distribution of relative turtle abundance (95\% represents total area and 50\% represents hotspots) based on sightings (a) before and during the scallop harvest season, and (b) in relation to vessel density (cell size $=500 \times 500 \mathrm{~m}$ ) during the scallop harvest season.
Currently, the scallop fishery is open access, with regulations set only on individual bag limits and no monitoring of the number of users or the spatial extent of the fishery (Geiger et al., 2015). The fishery attracts thousands of users each year to centralized, easily accessible locations with high scallop densities (Greenawalt-Boswell et al., 2007). This has the potential to affect turtle distributions, increase mortality from vessel strikes, and damage sensitive seagrass habitat (NMFS \& USFWS, 1991; NMFS et al., 2011). Despite the overlap between marine turtles and the scallop fishery, the potential impact on marine turtles in the region is unknown.

To investigate the potential impacts of recreational fisheries on marine turtles we first explored the distribution of marine turtles before and during the scallop harvest season, and assessed the overlap between recreational harvesters and turtles. We then evaluated if home ranges of individual turtles changed before and during the scallop harvest season and whether associated boating activities from the recreational scallop fishery affected marine turtle behaviour.

\section{Study area}

This study was conducted in the coastal waters of the upper Eastern Gulf of Mexico in the vicinity of Crystal River in Citrus County (Fig. 1). The study area contains three management areas designed to promote the conservation and restoration of aquatic resources: St. Martins Marsh Aquatic Preserve, Chassahowitzka National Wildlife Refuge, and a Manatee Protection Zone (Supplementary Fig. 1). The region has been identified as important marine habitat for green, loggerhead, and Kemp's ridley marine turtles (Schmid, 1998; Barichivich, 2006; Eaton et al., 2008) and is also a popular area for recreational harvest of the bay scallop, a species of ecological and economic importance in the region (Geiger et al., 2015). Some species of turtles, loggerhead and Kemp's ridley turtles in particular, have been reported to feed on scallops and other bivalves (Burke et al., 1994; Makowski et al., 2006; Warden, 2011). The harvest area spans $430 \mathrm{~km}$ of coast (Supplementary Fig. 1), and is particularly popular in Steinhatchee, Port St Joe, and Crystal River/Homosassa Springs. The 2016 scallop harvest season was 25 June-24 September.

\section{Methods}

\section{Vessel and turtle sighting distribution}

Vessel locations were obtained by randomly selecting the northern or southern boundary of the study area and then systematically recording the location of each vessel from north to south or south to north, dependent on start location, using a laser rangefinder with a global positioning system (GPS). One continuous transect was performed during each survey day, for a total of 7 transects before the scallop harvest season, and 10 transects during the season (Supplementary Table 1). Turtle sightings were recorded opportunistically when observed during vessel surveys. Vessel and turtle sightings were standardized based on the number of survey days in each season. Survey days were randomly selected within each month, between 22 May and 24 September 2016.

A separate 10-day trip was conducted to capture and tag turtles. Turtles were captured using the rodeo technique (Limpus \& Walter, 1980; Fuentes et al., 2006) and by dipnet, and brought to the boat to be processed. Standard straight carapace length ( $\pm 0.1 \mathrm{~cm}$; SCL) was measured from the anterior point at midline (nuchal scute) to the posterior tip of the supracaudals (Balazs, 1999). Each individual turtle was marked with two Inconel flipper tags (Style 681, National Band and Tag Company, Newport, USA) and a passive integrated transponder (PIT tag, Biomark, GPT12; Balazs, 
1999). Turtles were also checked for the presence of fibropapillomatosis; only visibly healthy turtles without fibropapillomatosis were considered for satellite tag deployment.

We deployed Argos-linked Fastloc GPS (Wildlife Computers SPLASH 10-BF-351E, Redmond, USA) tags on two green turtles, one Kemp's ridley and one loggerhead turtle during 5 May-11 June 2016, prior to the scallop season (Supplementary Table 2). Satellite tags were attached using the methods described by Seney et al. (2010) for small juvenile turtles, which allows for the increased growth rates of smaller turtles while minimizing transmitter loss. Turtles were kept on board for a maximum of $2 \mathrm{~h}$, to reduce behaviour disruption. Satellite-derived GPS positions of each turtle were extracted from early June until the last location was transmitted. Positions were then filtered to exclude very low accuracy Argos fixes (A, B, Z) and remove temporal/spatial duplicates and locations with unlikely travel and turning speeds, using the data-driven SDL filter (Shimada et al., 2012) in $R$ v. 3.4.3 (R Core Team, 2017). A second manual filter was applied to remove fixes located on land and obvious erroneous fixes that might not have been depicted by the SDL filter (e.g. too far away). Temporal distribution of filtered fixes is shown in Supplementary Fig. 2.

\section{Data analysis}

We used the Kernel Density Analysis tool in ArcGIS 10.3 (ESRI, Redlands, USA) and the isopleth function in GME 0.7.3 (Beyer, 2012) to identify the density, distribution area (where 95\% of sightings were recorded) and hotspots (where $50 \%$ of sightings were recorded) of harvest vessels and marine turtles. The distribution area of marine turtles before and during the scallop harvest season, and between marine turtles and vessels during the scallop harvest season, were compared qualitatively. To quantify the percentage of overlap between vessels and marine turtle areas during the harvest season, we used the Zonal Statistics as Table tool in ArcGIS.

To estimate home ranges and core areas of tracked turtles we considered all filtered locations for each season (before and during scallop harvest season; Supplementary Table 2), and computed utilization distribution, applying a movementbased kernel density estimation based on a biased random bridge model (Benhamou, 2011) with the package adehabitatHR (Calenge, 2011) in $R$. Home ranges were defined as the $95 \%$ utilization distribution and core areas as the $50 \%$ utilization distribution.

We employed a Behavioral Change Point Analysis (Gurarie et al., 2009) to assess potential changes in the movement behaviour of the tracked turtles 2 weeks before and after the beginning of the harvest season ( 25 June 2016). Change points, which are moments in time in which the Behavioral Change Point Analysis identified a significant change in behaviour, were assessed based on their
TABLE 1 Size of home ranges (95\% utilization distribution) and core areas (50\% utilization distribution) of individual green Chelonia mydas, Kemp's ridley Lepidochelys kempii and loggerhead Caretta caretta turtles tracked with satellite telemetry, before and during scallop harvest season.

\begin{tabular}{|c|c|c|c|c|}
\hline \multirow[b]{2}{*}{ Turtle ID } & \multicolumn{2}{|c|}{ Before scallop season } & \multicolumn{2}{|c|}{$\begin{array}{l}\text { During scallop } \\
\text { season }\end{array}$} \\
\hline & $\begin{array}{l}\text { Home } \\
\text { range } \\
\left(\mathrm{km}^{2}\right)\end{array}$ & $\begin{array}{l}\text { Core } \\
\text { area } \\
\left(\mathrm{km}^{2}\right)\end{array}$ & $\begin{array}{l}\text { Home } \\
\text { range } \\
\left(\mathrm{km}^{2}\right)\end{array}$ & $\begin{array}{l}\text { Core } \\
\text { area } \\
\left(\mathrm{km}^{2}\right)\end{array}$ \\
\hline \multicolumn{5}{|c|}{ Green turtles } \\
\hline Cm_1 & 194.5 & 29.6 & 54.5 & 6.2 \\
\hline $\mathrm{Cm} \_2$ & 5.9 & 1.3 & 2.0 & 0.4 \\
\hline \multicolumn{5}{|c|}{ Kemp's ridley turtle } \\
\hline Lk_1 & 5.4 & 0.8 & 14.5 & 1.7 \\
\hline \multicolumn{5}{|c|}{ Loggerhead turtle } \\
\hline Cc_1 & 44.2 & 8.6 & 35.4 & 7.3 \\
\hline
\end{tabular}

proximity to the beginning of season date. The values of the movement parameters (persistence velocity, variability in persistence velocity, tortuosity and travel speed) were compared before and after the significant change points. Persistence velocity is a measure that accounts for speed and directionality of the individual, and tortuosity is a measure of how much an individual turns.

\section{Results}

Spatial distribution of marine turtle and vessel sightings

We recorded 14.9 \pm SD 12.4 marine turtles per day and 36.3 \pm SD 33.7 vessels per day before the scallop harvest season, and $12.7 \pm$ SD 10.9 marine turtles per day and $260.1 \pm$ SD 151.8 vessels per day during the scallop season. The majority of vessels observed along the transects were stationary, and were probably engaging in scallop and fishing activities. In terms of turtle-vessel interactions, we did not witness any boat-strikes during the surveys but turtles were commonly observed fleeing from our research vessel. The relative distribution of marine turtles, particularly the distribution of marine turtle hotspots, shifted before and during the scallop harvest season (Fig. 1a). Additionally, during the scallop harvest season $48 \%$ of the relative turtle distribution area overlapped with vessels (Fig. 1b), with a mean of 4.5 vessels per $500 \mathrm{~m}^{2}$ grid cell (range o-33 vessels per cell).

\section{Changes in individual marine turtle distribution}

Mean home range size was $70 \pm \mathrm{SD} 84.6 \mathrm{~km}^{2}$ before the scallop harvest season, and $27.5 \pm \mathrm{SD} 22.6 \mathrm{~km}^{2}$ during the scallop harvest season (Table 1; Fig. 2). Average core area was $10.2 \pm$ SD $13.4 \mathrm{~km}^{2}$ before and $4.1 \pm \mathrm{SD} 3.2 \mathrm{~km}^{2}$ during the scallop harvest season (Table 1; Fig. 2). Home ranges and 


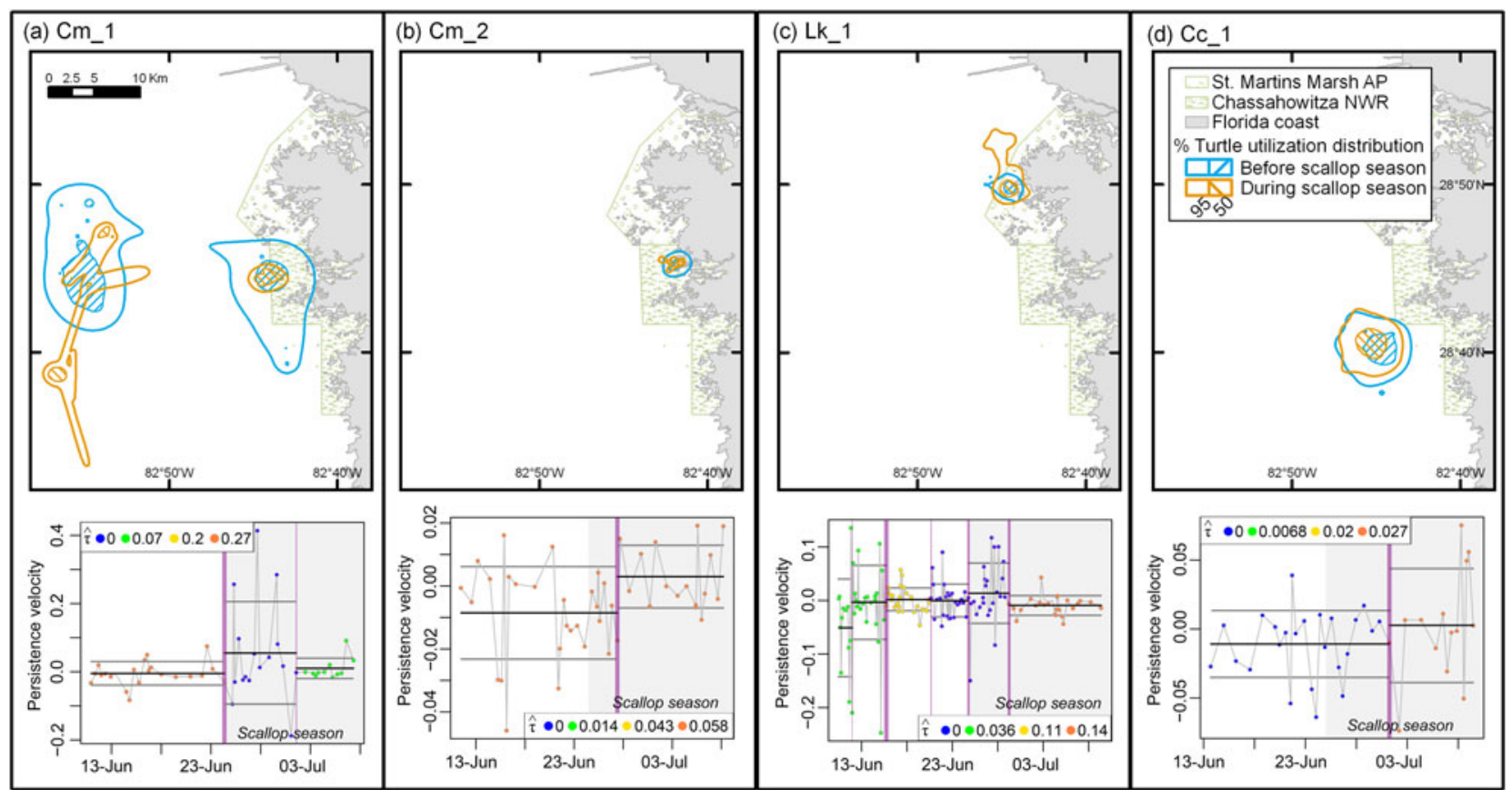

FIG. 2 Home ranges (95\% utilization distribution) and core area (50\% utilization distribution) (upper panels), and changes in behaviour (lower panels) of four turtles tracked with satellite telemetry. Black horizontal midline, mean persistence velocity; grey hoizontal outer lines, variability (standard deviation) of persistence velocity; $\tau$, tortuosity (cooler colours indicate relative straighter movements, whereas warmer colours indicate more relative tortuous movements); vertical purple lines, significant change points (indicative of significant changes in turtle behaviour); grey shaded area, scallop harvest season. AP, Aquatic Preserve; NWR, National Wildlife Refuge.

core areas appear to be on average smaller during the scallop harvest season, but the small sample size impeded statistical assessment of these observations. The spatial distribution of home ranges before and during the scallop season varied among individuals, with no consistent pattern: Cm_1 used multiple areas near- and further offshore, $\mathrm{Cm} \_2$ and $\mathrm{Lk} \_1$ remained in near-shore waters, and Cc_1 remained relatively nearshore during both periods.

\section{Changes in individual marine turtle behaviour}

In general, a significant change point was identified on the day (Fig. 2a, c) or close to the beginning of the scallop harvest season (Fig. 2b, d). In all cases, there was an increase in the persistence velocity after the significant change point (Fig. 2; Table 2). The travel speed and variability in the persistence velocity of three of four turtles increased after the change point, whereas tortuosity varied among individuals (Fig. 2; Table 2).

\section{Discussion}

Our study indicates that scallop recreational fisheries can potentially influence the temporary distribution of marine turtles and drive changes in their movement ecology. It is likely that the observed changes (e.g. turtles shifting further nearshore, faster and more frequent movements during the scallop harvest season) are a behavioural response to the seasonal increase in the presence of boats (moving and stationary) and people (snorkelling) within the turtles' habitat. Based on interviews carried out in a larger study of the perceptions and motivation of boaters in Crystal River, $<90 \%$ of respondents indicated they use the area for scalloping and fishing (MMPBF, pers. obs.). Practices employed to harvest scallops recreationally include travelling and anchoring boats, and snorkelling at depths of $1-3 \mathrm{~m}$ to manually remove the scallops from the seagrass beds (FWC, 2017). These harvest practices are unlikely to pose an imminent risk to marine turtles, compared to entanglement and potential mortality in fishing nets and lines used in other coastal fisheries (Sasso \& Epperly, 2006; Gilman et al., 2010). However, marine turtles are probably startled by the presence of high numbers of boats and swimmers (Hodgson \& Marsh, 2007; Powell \& Wells, 2011), which can lead to changes in their behaviour and could potentially have repercussions for their fitness.

Boating and fishing activities in nearshore areas can affect ecosystems at different levels, from individual fitness and population dynamics to changes in the physical structure of the habitat, community structure and ecosystem processes (Auster \& Langton, 1999). At the individual level, higher exposure to vessels increases the risk of boat-strikes (Hazel et al., 2007) and noise pollution (Samuel et al., 2005), 
TABLE 2 Individual behavioural parameters of movement bouts before and after the closest significant change point to the beginning of the scallop harvest season (25 June 2016).

\begin{tabular}{|c|c|c|c|c|c|c|c|}
\hline \multirow[b]{2}{*}{ Turtle ID } & \multirow{2}{*}{$\begin{array}{l}\text { Date of first fix after sig- } \\
\text { nificant change point }\end{array}$} & \multicolumn{2}{|c|}{$\begin{array}{l}\text { Travel speed } \\
(\mathrm{km} / \mathrm{h})\end{array}$} & \multicolumn{2}{|c|}{$\underline{\text { Persistence velocity } \pm \text { SD }}$} & \multicolumn{2}{|c|}{ Tortuosity } \\
\hline & & Before & After & Before & After & Before & After \\
\hline \multicolumn{8}{|c|}{ Green turtles } \\
\hline Cm_1 & 25 June & 0.163 & 0.629 & $0.005 \pm 0.034$ & $0.055 \pm 0.150$ & 0.270 & 0.007 \\
\hline $\mathrm{Cm} \_2$ & 27 June & 0.060 & 0.047 & $0.009 \pm 0.015$ & $0.003 \pm 0.010$ & 0.058 & 0.056 \\
\hline \multicolumn{8}{|c|}{ Kemp's ridley turtle } \\
\hline Lk_1 & 25 June & 0.153 & 0.248 & $0.000 \pm 0.031$ & $0.013 \pm 0.056$ & 0.001 & 0.001 \\
\hline \multicolumn{8}{|c|}{ Loggerhead turtle } \\
\hline Cc_1 & 2 July & 0.109 & 0.163 & $0.011 \pm 0.024$ & $0.003 \pm 0.041$ & 0.000 & 0.027 \\
\hline
\end{tabular}

which can also have implications on the species' foraging behaviour and energy budgets (Jones \& Seminoff, 2013). In terms of behaviour, the presence of vessels and associated noise can alter regular behavioural patterns, by decreasing surfacing time and increasing flight responses to escape or avoid a perceived threat (Hazel et al., 2007; Wirsing et al., 2008). Such movements correspond with the increase in speed and directionality identified for the turtles tracked, and could explain the lower rate and quality of satellitederived locations received during the scallop harvest season. Frequent flight movements will probably increase the metabolic rate of individuals, and energy expenditure, which in turn decreases the internal energy available for storage and somatic growth (Hamann et al., 2002; Jones \& Seminoff, 2013). Further investigation of how the observed distributional and behavioural changes relate to the foraging ecology and overall energy expenditure of turtles in the region is warranted. This would provide insights into the direct impact of recreational fisheries on turtles, and the overall impact from the high density of boats and swimmers.

Indirect effects of recreational fisheries to marine turtles could occur through impacts on seagrass beds (Hallac et al., 2012), which are important habitats for several species of marine turtles (Bjorndal et al., 1997; Schmid et al., 2003; Bjorndal \& Bolten, 2010). A major impact of boating activities in coastal habitats is the fragmentation and degradation of seagrass beds as a result of extensive scarring and anchoring. The fragmentation of seagrass beds negatively affects the growth and regeneration rates of seagrass species, disrupts associated invertebrate communities, increases erosion and suspended sediments (thus decreasing visibility), and has been linked to decreasing biodiversity in coastal habitats (Hallac et al., 2012; Nordlund \& Gullstrom, 2013). Problems derived from seagrass scarring have been highlighted during multiple and extensive seagrass monitoring programmes along the Eastern Gulf of Mexico (FWC, 2013), and can indirectly affect availability and quality of food for turtles in the region. It is possible that damage to marine turtle foraging habitat is influencing the changes in distribution of turtles during and after the scallop season. Marine turtle hotspots outside the scallop harvest season appear to overlap with areas highly used by harvesters during the scallop harvest season, whereas marine turtle hotspots during the scallop harvest season appear to shift and not overlap as much with areas of high vessel density. Nevertheless, these results should be interpreted with caution, given that turtle sightings were recorded opportunistically. However, it is likely that the number of turtles that actually overlap with the scallop fishing area is higher than we recorded, given that limited accessibility to high density vessel areas hinders the detection of turtles. Changes in the relative distribution of individuals between seasons can alter the dynamics of the marine turtle populations, increasing density of turtles in patches avoided by harvesters, which are probably the less damaged habitats.

Marine turtle distributions are influenced by multiple factors including, but not limited to, local and oceanic currents (e.g. Wildermann et al., 2017), abundance and access to prey (Witt et al., 2007), shelter (Christiansen et al., 2017), presence of predators (Heithaus, 2013), and seasonal shifts in water parameters (Schmid \& Witzell, 2006; Shimada et al., 2016). Moreover, intra- and inter-specific differences in behaviour are also common among marine turtles. For example, distributional dichotomy has been shown in green turtles, which have distinctive resting (nocturnal) and foraging (diurnal) areas within their home range (Makowski et al., 2006; Christiansen et al., 2017). Such behaviour could explain the use of multiple patches by turtle Cm_1 (Fig. 2). Temperature-dependent changes in behaviour are also typical between seasons (summer/winter) (Schmid \& Witzell, 2006). Home range size is expected to increase in the summer when turtles are more active (Shimada et al., 2016) but our results show an apparent decrease in home range size following the start of the scallop harvest season. Given that the tracking of turtles took place during summer months (June-August) when average water temperatures are fairly constant $\left(28.8-30{ }^{\circ} \mathrm{C}\right.$; NOAA, 2017), it is unlikely that temperature had a substantial influence in the observed changes. Nevertheless, further integrative 
studies including comprehensive habitat characterization (Bestley et al., 2013), stable isotope analysis (Pajuelo et al., 2016) and fine-scale behavioural ecology (Okuyama et al., 2010; Watanabe \& Takahashi, 2013) are needed to evaluate the extent to which other factors could be driving habitat selection and use by marine turtles in the region. This could provide further insights into the direct and indirect impacts of recreational fisheries on marine turtles.

Understanding the interaction between anthropogenic pressures and marine species is vital to inform local management and conservation practices. Marine turtles in nearshore habitats reportedly tend to avoid areas with high human activity related to heavy boat traffic or intensive fishing (Renaud et al., 1995; Seminoff et al., 2002). The largest effect of the vessel-turtle interaction in Crystal River is probably related to the presence of a high number of vessels engaged in harvest activities. To reduce this effect, management measures could focus on number of vessel quotas allowed in any given area, or maintaining a minimum distance between boats (Norman, 2009). Another mitigation strategy is the establishment of speed restrictions, such as go-slow zones (Calleson \& Frohlich, 2007; DERM, 2008). Areas used by turtles in the study area are within zones that do not have speed regulations and/or the $40 \mathrm{~km} / \mathrm{h}$ speed zone of the Manatee Protection Zone. Such speeds are probably too fast for turtles to avoid collisions. Green turtles have been reported to react to vessels when the boat speed is up to $4 \mathrm{~km} / \mathrm{h}$ (Hazel et al., 2007). Although the area used by marine turtles is too large to be transformed entirely into a go-slow zone, slow speed areas could be expanded to include marine turtle hotspots. We recommend marine turtle behaviour should be considered in the planning of future management actions in coastal areas along the Eastern Gulf of Mexico.

In conclusion, our study highlights the importance of considering recreational fisheries when assessing the spatial ecology of coastal marine turtle populations, even though the fishing practices in use might not pose an evident imminent risk to the species. The cumulative and synergistic exposure of marine turtles to direct and indirect pressures derived from recreational fisheries, in addition to other natural and atrophic threats, can have detrimental effects on the overall persistence of turtle populations (Fuentes et al., 2011; Maxwell et al., 2013). Further studies on seasonal effects on marine turtle behaviour and habitat use in the study area are needed. Such studies would benefit from more tracking data before, during and after the scallop harvest season. In addition, studies that quantify the response of marine turtles to the presence of vessels (e.g. using animal-borne technologies), and assess the medium- and long-term impact of the scallop and other recreational fisheries on the fitness and population dynamics of marine turtle populations would be informative for management purposes.

\section{Acknowledgements}

We appreciate the support provided by the Department of Environmental Protection of Florida, the Marine Turtle Research Ecology and Conservation Group at Florida State University, Inwater Research Group Inc., and the National Oceanic and Atmospheric Administration. This research was partly supported by the Florida Sea Turtle License Plate grant, and permitted by: National Marine Fisheries Service ESA Section 10(a) permit (\#16733, \#19496), Florida Fish and Wildlife Conservation Commission Marine Turtle Permit (MTP-16-30, MTP-16-243, MTP-17-243A), Research and Monitoring Special Use permit for Chassahowitzka (\#41510-14002, \#16011), and Florida Animal Care and Use Committee permit (ACUC \#1524). We appreciate the critiques of the Editor and reviewers. All authors declare that there are no conflicts of interest.

\section{Author contributions}

MMPBF and CG designed the study, MMPBF, CG and CS carried out the fieldwork and NW carried out the analysis. NW and MMPBF wrote the manuscript, and CS and CG helped with editing and comments.

\section{References}

Altieri, A.H., Bertness, M.D., Coverdale, T.C., Herrmann, N.C. \& Angelini, C. (2012) A trophic cascade triggers collapse of a salt-marsh ecosystem with intensive recreational fishing. Ecology, 93, 1402-1410.

Auster, P. \& Langton, R. (1999) The effects of fishing on fish habitat. In American Fisheries Society Symposium, 22, 150-187.

BALAZs, G. (1999) Factors to consider in the tagging of sea turtles. In Research and Management Techniques for the Conservation of Sea Turtles. (eds K.L. Eckert, K. Bjorndal, F. A. Abreu-Grobois \& M. Donnelly), pp. 101-114. IUCN Species Survival Commission, Marine Turtle Specialist Group, Washington, DC, USA.

BARICHIVICH, W.J. (2006) Characterization of a marine turtle aggregation in the big bend of Florida. MSc thesis. University of Florida, Gainesville, USA.

Barrios-Garrido, H. \& Montiel-Villalobos, M.G. (2016) Strandings of leatherback turtles (Dermochelys coriacea) along the Western and Southern Coast of the Gulf of Venezuela.

Herpetological Conservation and Biology, 11, 244-252.

Benhamou, S. (2011) Dynamic approach to space and habitat use based on biased random bridges. Plos One, 6, e14592.

Bestley, S., Jonsen, I.D., Hindell, M.A., Guinet, C. \& Charrassin, J.B. (2013) Integrative modelling of animal movement: incorporating in situ habitat and behavioural information for a migratory marine predator. Proceedings of the Royal Society B Biological Sciences, 280, 20122262.

Beyer, H.L. (2012) Geospatial Modelling Environment (v. 0.7.3.o). Http://www.spatialecology.com/gme [data accessed July 2017].

BJorndal, K.A. \& Bolten, A.B. (2010) Hawksbill sea turtles in seagrass pastures: success in a peripheral habitat. Marine Biology, 157, 135-145.

Bjorndal, K.A., Lutz, P. \& Musick, J. (1997) Foraging ecology and nutrition of sea turtles. The Biology of Sea Turtles, 1, 199-231.

Burke, V.J., Morreale, S.J. \& Standora, E.A. (1994) Diet of the Kemp's ridley sea turtle, Lepidochelys kempii, in New York waters. Fishery Bulletin, 92, 26-32. 
CAlenge, C. (2011) Home Range Estimation in R: the adehabitatHR Package. Https://cran.r-project.org/web/packages/adehabitatHR/ vignettes/adehabitatHR.pdf [accessed July 2017].

Calleson, C.S. \& Frohlich, R.K. (2007) Slower boat speeds reduce risks to manatees. Endangered Species Research, 3, 295-304.

Christiansen, F., Esteban, N., Mortimer, J.A., Dujon, A.M. \& HAYs, G.C. (2017) Diel and seasonal patterns in activity and home range size of green turtles on their foraging grounds revealed by extended Fastloc-GPS tracking. Marine Biology, 164, 10.

Cooke, S.J. \& Cowx, I.G. (2004) The role of recreational fishing in global fish crises. BioScience, 54, 857-859.

Crowder, L. \& Norse, E. (2008) Essential ecological insights for marine ecosystem-based management and marine spatial planning. Marine Policy, 32, 772-778.

DERM (2008) Marine Parks (Moreton Bay) Zoning Plan 2008. Department of Environment and Resource Management, Brisbane, Australia.

Eaton, C., McMichael, E., Witherington, B., Foley, A., Hardy, R. \& Meylan, A. (2008) In-water Sea Turtle Monitoring and Research in Florida: Review and Recommendations. Florida Fish and Wildlife Conservation Commission, Fish and Wildlife Research Institute, St Petersburg, USA.

Fuentes, M.M.P.B., Lawler, I.R. \& Gyuris, E. (2006) Dietary preferences of juvenile green turtles (Chelonia mydas) on a tropical reef flat. Wildlife Research, 33, 671-678.

Fuentes, M.M.P.B., Limpus, C.J. \& Hamann, M. (2011) Vulnerability of sea turtle nesting grounds to climate change. Global Change Biology, 17, 140-153.

FWC (2013) Seagrass Integrated Mapping and Monitoring Program: Mapping and Monitoring Report No.1. Fish and Wildlife Research Institute, St Petersburg, USA.

FWC (2017) Bay Scallop Recreational Harvest Regulations. Http:// www.myfwc.com/fishing/saltwater/recreational/bay-scallops/ [accessed November 2017].

Geiger, S., Parker, M., Stephenson, S., Radigan, R., Hurley, A., Kirby, C. et al. (2015) Florida Bay Scallop 2014 Annual Report. Fish and Wildlife Research Institute, St Petersburg, USA.

Gilman, E., Gearhart, J., Price, B., Eckert, S., Milliken, H., WANG, J. et al. (2010) Mitigating sea turtle by-catch in coastal passive net fisheries. Fish and Fisheries, 11, 57-88.

Greenawalt-Boswell, J., Frazer, T.K., Jacoby, C.A. \& Arnold, W.S. (2007) Mortality and exploitation rate estimates for the recreational bay scallop fishery off the Gulf Coast of Florida, USA. North American Journal of Fisheries Management, 27, 1230-1242.

Gurarie, E., Andrews, R.D. \& Laidre, K.L. (2009) A novel method for identifying behavioural changes in animal movement data. Ecology Letters, 12, 395-408.

Hallac, D.E., Sadle, J., Pearlstine, L., Herling, F. \& Shinde, D. (2012) Boating impacts to seagrass in Florida Bay, Everglades National Park, Florida, USA: links with physical and visitor-use factors and implications for management. Marine and Freshwater Research, 63, 1117-1128.

Hamann, M., Limpus, C.J. \& Whittier, J.M. (2002) Patterns of lipid storage and mobilisation in the female green sea turtle (Chelonia mydas). Journal of Comparative Physiology B, 172, 485-493.

Hazel, J., Lawler, I., Marsh, H. \& Robson, S. (2007) Vessel speed increases collision risk for the green turtle Chelonia mydas. Endangered Species Research, 3, 105-113.

Heithaus, M.R. (2013) Predators, prey, and the ecological roles of sea turtles. In The Biology of Sea Turtles, Vol. 3 (eds J. Wyneken, K. J. Lohmann \& J.A. Musick), pp. 249-284. CRC Press, Boca Raton, USA.

Hodgson, A.J. \& MARsh, H. (2007) Response of dugongs to boat traffic: The risk of disturbance and displacement. Journal of Experimental Marine Biology and Ecology, 340, 50-61.
Jones, T.T. \& Seminoff, J.A. (2013) Feeding biology: advances from field-based observations, physiological studies, and molecular techniques. In The Biology of Sea Turtles, Vol. 3 (eds J. Wyneken, K. J. Lohmann \& J.A. Musick), pp. 211-248. CRC Press, Boca Raton, USA.

Lewison, R.L., Crowder, L.B., Wallace, B.P., Moore, J.E., Cox, T., Zydelis, R. et al. (2014) Global patterns of marine mammal, seabird, and sea turtle bycatch reveal taxa-specific and cumulative megafauna hotspots. Proceedings of the National Academy of Sciences of the United States of America, 111, 5271-5276.

Limpus, C. \& Walter, D. (1980) The growth of immature green turtles (Chelonia mydas) under natural conditions. Herpetologica, $36,162-165$.

Makowski, C., Seminoff, J.A. \& Salmon, M. (2006) Home range and habitat use of juvenile Atlantic green turtles (Chelonia mydas L.) on shallow reef habitats in Palm Beach, Florida, USA. Marine Biology, 148, 1167-1179.

Maxwell, S.M., Hazen, E.L., Bograd, S.J., Halpern, B.S., Breed, G.A., NiCKeL, B. et al. (2013) Cumulative human impacts on marine predators. Nature Communications, 4, 2688.

NMfS (National Marine Fisheries Service) (2017) The Marine recreational fishing statistics survey, queries. Http://www.st.nmfs. noaa.gov/recreational-fisheries/access-data/run-a-data-query/index [accessed September 2017].

NMFS \& USFWS (National Marine Fisheries Service \& United States Fish and Wildlife Service) (1991) Recovery Plan for U.S. Population of Atlantic Green Turtle. Recovery Plan. National Marine Fisheries Service, Washington, DC, USA.

NMFS, USFWS \& SEMARNAT (National Marine Fisheries Service, United States Fish and Wildlife Service \& SEMARNAT) (2011) Bi-National Recovery Plan for the Kemp's Ridley Sea Turtle (Lepidochelys kempii). Recovery Plan. National Marine Fisheries Service, Silver Springs, USA.

NOAa (National Oceanic and Atmospheric Association) (2017) Water Temperature Table of the Eastern Gulf of Mexico. Https://www.nodc.noaa.gov/dsdt/cwtg/all_meanT.html [accessed November 2017].

Nordlund, L.M. \& Gullstrom, M. (2013) Biodiversity loss in seagrass meadows due to local invertebrate fisheries and harbour activities. Estuarine Coastal and Shelf Science, 135, 231-240.

Norman, B. (2009) ECOCEAN 'Best Practice' Whale Shark Ecotourism Manual. Http://sustainablesharkdiving.com/wp-content/uploads/ 2016/03/ECOCEAN-Best-Practice-Whale-Shark-EcotourismUNEP-MANUAL.pdf [accessed April 2018].

Okuyama, J., Kawabata, Y., Naito, Y., Arai, N. \& Kobayashi, M. (2010) Monitoring beak movements with an acceleration datalogger: a useful technique for assessing the feeding and breathing behaviors of sea turtles. Endangered Species Research, 10, 39-45.

Pajuelo, M., Bjorndal, K.A., Arendt, M.D., Foley, A.M., Schroeder, B.A., Witherington, B.E. \& Bolten, A.B. (2016) Long-term resource use and foraging specialization in male loggerhead turtles. Marine Biology, 163, 235.

Powell, J.R. \& Wells, R.S. (2011) Recreational fishing depredation and associated behaviors involving common bottlenose dolphins (Tursiops truncatus) in Sarasota Bay, Florida. Marine Mammal Science, 27, 111-129.

R Core Team (2017) R: a language and environment for statistical computing. R Foundation for Statistical Computing, Vienna, Austria. Http://www.R-project.org [accessed November 2017].

Renaud, M.L., Carpenter, J.A. \& Williams, J.A. (1995) Activities of juvenile green turtles, Chelonia mydas, at a jettied pass in south Texas. Fishery Bulletin, 93, 586-593. 
Samuel, Y., Morreale, S.J., Clark, C.W., Greene, C.H. \& Richmond, M.E. (2005) Underwater, low-frequency noise in a coastal sea turtle habitat. The Journal of the Acoustical Society of America, 117, 1465-1472.

SAsso, C.R. \& EpPerLy, S.P. (2006) Seasonal sea turtle mortality risk from forced submergence in bottom trawls. Fisheries Research, 81, 86-88.

Schmid, J.R. (1998) Marine turtle populations on the west-central coast of Florida: Results of tagging studies at the Cedar Keys, Florida 1986-1995. Fishery Bulletin, 96, 589-602.

Schmid, J.R., Bolten, A.B., Bjorndal, K.A., LindberG, W.J., Percival, H.F. \& Zwick, P.D. (2003) Home range and habitat use by Kemp's ridley turtles in west-central Florida. Journal of Wildife Management, 67, 196-206.

SCHMid, J.R. \& WitZeLL, W.N. (2006) Seasonal migrations of immature Kemp's Ridley turtle (Lepidochelys kempii Garman) along the West Coast of Florida. Gulf of Mexico Science, 1, 28-40.

Seminoff, J.A., Resendiz, A. \& Nichols, W.J. (2002) Home range of green turtles Chelonia mydas at a coastal foraging area in the Gulf of California, Mexico. Marine Ecology Progress Series, $242,253-265$.

Seney, E.E., Higgins, B.M. \& Landry, A.M. (2010) Satellite transmitter attachment techniques for small juvenile sea turtles. Journal of Experimental Marine Biology and Ecology, 384, 61-67.

Shimada, T., Jones, R., Limpus, C., Groom, R. \& Hamann, M. (2016) Long-term and seasonal patterns of sea turtle home ranges in warm coastal foraging habitats: implications for conservation. Marine Ecology Progress Series, 562, 163-179.

Shimada, T., Jones, R., Limpus, C. \& Hamann, M. (2012) Improving data retention and home range estimates by data-driven screening. Marine Ecology Progress Series, 457, 171-180.

Wallace, B.P., Kot, C.Y., DiMatteo, A.D., Lee, T., Crowder, L.B. \& LEWISON, R.L. (2013) Impacts of fisheries bycatch on marine turtle populations worldwide: toward conservation and research priorities. Ecosphere, 4, 1-49.

WARDEN, M.L. (2011) Modeling loggerhead sea turtle (Caretta caretta) interactions with US Mid-Atlantic bottom trawl gear for fish and scallops, 2005-2008. Biological Conservation, 144, 2202-2212.
Watanabe, Y.Y. \& Takahashi, A. (2013) Linking animal-borne video to accelerometers reveals prey capture variability. Proceedings of the National Academy of Sciences of the United States of America, 110, 2199-2204.

Wildermann, N., Critchell, K., Fuentes, M., Limpus, C.J., Wolanski, E. \& Hamann, M. (2017) Does behaviour affect the dispersal of flatback post-hatchlings in the Great Barrier Reef? Royal Society Open Science, 4, 170164.

Wirsing, A.J., Abernethy, R. \& Heithaus, M.R. (2008) Speed and maneuverability of adult loggerhead turtles (Caretta caretta) under simulated predatory attack: do the sexes differ? Journal of Herpetology, 42, 411-413.

Witt, M.J., Broderick, A.C., Johns, D.J., Martin, C., Penrose, R., Hoogmoed, M.S. \& Godley, B.J. (2007) Prey landscapes help identify potential foraging habitats for leatherback turtles in the NE Atlantic. Marine Ecology Progress Series, 337, 231-243.

Young, M.A.L., Foale, S. \& Bellwood, D.R. (2014) Impacts of recreational fishing in Australia: historical declines, self-regulation and evidence of an early warning system. Environmental Conservation, 41, 350-356.

Zydelis, R., Wallace, B.P., Gilman, E.L. \& Werner, T.B. (2009) Conservation of marine megafauna through minimization of fisheries bycatch. Conservation Biology, 23, 608-616.

\section{Biographical sketches}

Natalie Wildermann's research focuses on applying spatial and movement ecology analysis to inform management and conservation of marine megafauna. Christopher SAsso has expertise in sea turtle stock assessment, impact of fisheries on marine populations and satellite tag-telemetry studies. Christian Gredzens researches marine species conservation and how the biology and ecology of these species can be used for effective management strategies. Mariana M. P. B. FuENTES' carries out research to develop science-based solutions for the conservation and management of marine megafauna, in particular marine turtles. 